\title{
Limestone particle sizes and lighting regimens on egg and bone quality of laying hens
}

\author{
Regina Patrícia de Souza Xavier(1), Ednardo Rodrigues Freitas ${ }^{(1)}$, Nádia Melo Braz ${ }^{(1)}$, \\ Nadja Naiara Pereira Farias ${ }^{(1)}$, Raffaella Castro Lima ${ }^{(1)}$, Pedro Henrique Watanabe ${ }^{(1)}$, \\ Germano Augusto Jerônimo Nascimento( ${ }^{(1)}$ and Maria Simone Mendes Peixoto(1)
}

(1)Universidade Federal do Ceará, Centro de Ciências Agrárias, Departamento de Zootecnia, Campus do Pici, Avenida Mister Hull, no 2.977,
Caixa Postal 12.168, CEP 60021970 Fortaleza, CE, Brazil. E-mail: r_patriciasx@hotmail.com, ednardo@ufc.br, nadia_zootec@yahoo.com.br,
nadja_naiara@hotmail.com, raffazoo@yahoo.com.br, pedro_watanabe@yahoo.com.br, germanoaugusto@ufc.br, simoneufc@hotmail.com

Abstract - The objective of this work was to evaluate the effect of limestone particle sizes in the diet and of lighting regimes on the egg and bone quality and on the performance of commercial laying hens. Three hundred Hissex White layers, at 18 weeks of age, were distributed in a completely randomized design, in a $5 \times 2$ factorial arrangement (coarse limestone in the diet at $0,25,50,75$, and $100 \%$; with or without artificial light), with five replicates of six birds. No significant interaction was observed between particle sizes and lighting regime for the evaluated parameters. There was no significant effect of coarse limestone level in the diet on the performance and egg quality of hens; however, bone deformity (3.23 to $4.01 \mathrm{~mm})$, strength (5.19 to $6.70 \mathrm{kgf} \mathrm{cm}^{-2}$ ), and mineral matter (51.09 to $59.61 \%$ ) improved as the proportion of coarse limestone increased. For lighting regime, the treatment with artificial light yielded higher Haugh unit values (87.17 vs. 85.54) than that with natural light only. Greater limestone particles improve bone quality of laying hens, and the use of artificial light can benefit the albumen quality of the eggs.

Index terms: egg mass, shell thickness, specific gravity, tibia.

\section{Tamanhos de partícula de calcário e regimes de luz na qualidade de ovos e ossos de galinhas poedeiras}

Resumo - O objetivo deste trabalho foi avaliar os efeitos de tamanhos de partículas de calcário na dieta e de regimes de luz artificial sobre a qualidade de ovos e de ossos e o desempenho de galinhas poedeiras comerciais. Utilizaram-se 300 poedeiras Hissex White, com 18 semanas de idade, distribuídas em delineamento inteiramente casualizado, em arranjo fatorial 5x2 (tratamentos com calcário grosso na dieta a $0,25,50,75$ e $100 \%$; com ou sem luz artificial), com cinco repetições de seis aves. Não se observou interação significativa entre o tamanho das partículas e a iluminação quanto aos parâmetros avaliados. Não houve efeito significativo da percentagem de calcário grosso na ração sobre o desempenho e a qualidade do ovo das galinhas; no entanto, a deformidade $(3,23 \mathrm{a} 4,01 \mathrm{~mm})$, a resistência à quebra $\left(5,19 \mathrm{a} 6,70 \mathrm{kgf} \mathrm{cm}^{-2}\right)$ e a matéria mineral dos ossos $(51,09 \mathrm{a} 59,61 \%)$ melhoraram com o aumento da proporção de calcário grosso. Quanto ao regime de iluminação, o tratamento com luz artificial apresentou maiores valores de unidade Haugh $(87,17$ vs. 85,54$)$ do que aquele apenas com luz natural. As maiores partículas de calcário melhoram a qualidade óssea das galinhas poedeiras, e a utilização da luz artificial pode favorecer a qualidade do albúmen dos ovos.

Termos para indexação: massa de ovo, espessura de casca, densidade específica, tíbia.

\section{Introduction}

Light energy is one of the physical environmental factors that interferes with the productive performance of birds. It affects the circadian rhythm which coordinates the schedule for biological, physiological, immunological, and behavioral events that will determine bird productive performance (Jácome et al., 2014). According to Gewehr \& Freitas (2007), some of the major effects of artificial light on laying birds are the possibilities of anticipation or delay in starting laying eggs, which influences the production rate, improves eggshell thickness, optimizes egg size, and maximizes feed efficiency of those birds.

The response to light stimuli is periodical, and the photosensitive phase of layers starts at approximately 11 hours after the start of light perception, after a 
dark period, and ends two hours later. Thus, short photoperiods do not reach the photosensitive phase, whereas longer periods do, stimulating the secretion of gonadotropins (Jácome et al., 2014). In this context, the number of hours of light received by laying hens can influence the egg production. However, for birds reared in open-sided houses, depending on the geographical location of the poultry farms and the season of the year, natural and artificial light should be combined to offer a number of light hours to allow hormone stimulation to produce eggs (Freitas et al., 2005; Jácome et al., 2014).

However, there is an expectation that in regions close to the Ecuador axis, it is possible to maintain the performance of laying hens only with natural lighting, since the annual variation in the number of hours of daily light is minimal, and there is the availability of at least 11 hours and 30 minutes of light per day during the year (Gewehr \& Freitas, 2007). Jácome et al. (2014) showed that layers are indeed photostimulated with more than 12 hours of light, independently of the artificial lighting program applied.

Other important aspects in the egg production of laying hens are the management strategy and nutrition, in order to reduce the loss of eggs because of problems in shell quality, and the association of this problem with bone quality of layers at the beginning and end of the production cycle. Faria et al. (2000) reported that offering feed at night, in association with the photoperiod, can increase the benefits for quality characteristics of shell eggs. Thus, ensuring food intake at night may increase the availability of calcium for eggshell formation. The change in the particle size of calcium sources have been studied with some positive results for the quality of eggshell (Lichovnikova, 2007; Skřivan et al., 2010) and bird bones (Saunders-Blades et al., 2009; Witt et al., 2009; Araújo et al., 2011; Cufadar et al., 2011; Oliveira et al., 2013; Tunç \& Cufadar, 2015), when larger particles of calcium sources are offered in the rations.

When particles of the calcium sources are larger, with a lower solubility, the digestive tract of birds is able to keep the blood calcium level available for the formation of eggshell even at night, which contributes to the maintenance of its quality. However, this effects do not happen when limestone particles are fine because they are easily solubilized, which contributes to the reduction of the calcium availability at night. When this happens, the bones become the main source of calcium for the synthesis of the shell (Saunders-Blades et al., 2009; Araújo et al., 2011). However, due to confounded effects, such as differences in calcium sources, particle sizes, age, and genotype of birds, as well as dietary calcium levels, it is difficult to make meaningful comparisons and final conclusions on a specific calcitic limestone source differing on particle sizes, and its effects on bone quality of layers at the end of the laying phase (Witt et al., 2009).

The objective of this work was to evaluate the effect of limestone particle sizes in the diet and of lighting regimes on the egg and bone quality and on the performance of commercial laying hens.

\section{Materials and Methods}

Three hundred commercial laying hens of Hissex White strain, with 18 weeks of age, were used for seven 21-day periods. Birds were distributed in a completely randomized design in a $5 \times 2$ factorial arrangement, with five replicates with six birds. The treatments were five limestone particle sizes, obtained by increasing the proportion of coarse limestone $(0,25,50,75$ and $100 \%)$ in relation to fine limestone, and two types of lighting regime - with or without artificial light.

Birds were distributed in wire cages $(0.25 \times 0.40 \times 0.30 \mathrm{~m})$, equipped with a linear galvanized-sheet trough, and an automatic nipple drinker, at the density of two birds per cage.

To apply the lighting programs, birds were housed in two sheds with similar structure, parallel to each other. To avoid influence of light in the sheds, black plastic curtains were installed on the sides of the sheds. Birds subjected to the use of artificial light received 14 hours of light (natural + artificial) per day, immediately after being transferred to the laying shed; 15-min light increments were made weekly until reaching 16 hours (natural + artificial), remaining constant until the end of the experiment. Birds subjected to natural light received 12 hours and $13 \mathrm{~min}$ of light per day, during all the experimental period.

The birds were fed ad libitum with formulated laying diets (Table 1), considering the feed composition values proposed by Rostagno et al. (2011), and the nutritional requirements proposed by the manual of the strain. The same limestone was used to meet the calcium 
requirements, but with different particle sizes, which were classified as coarse (GMD $2.03 \mathrm{~mm}$, and GSD $1.16 \%$ ), and fine (GMD $0.23 \mathrm{~mm}$, and GSD $1.06 \%$ ) by the supplier.

The evaluated performance variables, in the production phase, were laying percentage (\%), feed intake ( $g$ per bird per day), egg weight (g), egg mass (g per bird per day), and feed conversion $\left(\mathrm{g} \mathrm{g}^{-1}\right)$.

The quality of egg components was evaluated during the entire experimental period. Once a week, all eggs from each plot were collected, identified, and weighed on an electronic scale AD1000 - maximum 1,010 g with $\pm 0.01 \mathrm{~g}$ precision (Marte Balanças e Aparelhos de Precisão Ltda., Santa Rita do Sapucaí, MG, Brazil). From these, three eggs were selected per plot for assessment of quality and characteristics (avoiding broken, cracked, or dirty eggs). The analyzed variables were specific gravity and Haugh unit, whereas the egg trait variables were shell thickness and percentages of yolk, shell, and albumen (\%).

Egg specific gravity was determined according to procedures described by Freitas et al. (2004). Egg weight was determined on the scale precision $\mathrm{AD}$ 1000 , both in the air and in water, and the specific gravity was measured by the equation Specific gravity $=\mathrm{WA} /(\mathrm{WW} \times \mathrm{F})$, in which: WA is the egg weight in the air; WW is the egg weight in water; and $\mathrm{F}$ is the temperature correction factor.

After weighing, eggs were cracked and put onto a glass surface, for measuring the height of thick albumen

Table 1. Proximate and calculated nutritional composition of the experimental diets.

\begin{tabular}{|c|c|c|c|c|c|}
\hline \multirow{2}{*}{$\begin{array}{l}\text { Ingredients } \\
\left(\mathrm{g} \mathrm{kg}^{-1}\right)\end{array}$} & \multicolumn{5}{|c|}{ Coarse limestone: fine limestone level (\%) } \\
\hline & 100:0 & $75: 25$ & $50: 50$ & $25: 75$ & $0: 100$ \\
\hline$\overline{\text { Corn }}$ & 58.730 & 58.730 & 58.730 & 58.730 & 58.730 \\
\hline Soybean & 28.930 & 28.930 & 28.930 & 28.930 & 28.930 \\
\hline Coarse limestone & 8.450 & 6.337 & 4.225 & 2.113 & 0.000 \\
\hline Fine limestone & 0.000 & 2.113 & 4.225 & 6.337 & 8.450 \\
\hline Dicalcium phosphate & 1.890 & 1.890 & 1.890 & 1.890 & 1.890 \\
\hline Soybean oil & 1.230 & 1.230 & 1.230 & 1.230 & 1.230 \\
\hline Common salt & 0.400 & 0.400 & 0.400 & 0.400 & 0.400 \\
\hline Vitamin mineral supplement ${ }^{(1)}$ & 0.300 & 0.300 & 0.300 & 0.300 & 0.300 \\
\hline DL-methionine & 0.070 & 0.070 & 0.070 & 0.070 & 0.070 \\
\hline Total & 100.000 & 100.000 & 100.000 & 100.000 & 100.000 \\
\hline \multicolumn{6}{|l|}{ Nutritional composition } \\
\hline Linoleic acid $\left(\mathrm{g} \mathrm{kg}^{-1}\right)$ & 1.979 & 1.979 & 1.979 & 1.979 & 1.979 \\
\hline Calcium (\%) & 3.801 & 3.801 & 3.801 & 3.801 & 3.801 \\
\hline Metabolizable energy (Mcal kg-1) & 2.750 & 2.750 & 2.750 & 2.750 & 2.750 \\
\hline $\mathrm{NDF}^{(2)}(\%)$ & 10.705 & 10.705 & 10.705 & 10.705 & 10.705 \\
\hline $\operatorname{ADF}^{(3)}(\%)$ & 4.369 & 4.369 & 4.369 & 4.369 & 4.369 \\
\hline Crude fiber $(\%)$ & 2.710 & 2.710 & 2.710 & 2.710 & 2.710 \\
\hline Available phosphorus (\%) & 0.449 & 0.449 & 0.449 & 0.449 & 0.449 \\
\hline Total phosphorus (\%) & 0.644 & 0.644 & 0.644 & 0.644 & 0.644 \\
\hline Fat $(\%)$ & 3.737 & 3.737 & 3.737 & 3.737 & 3.737 \\
\hline Total lysine (\%) & 0.942 & 0.942 & 0.942 & 0.942 & 0.942 \\
\hline Dry matter (\%) & 88.976 & 88.976 & 88.976 & 88.976 & 88.976 \\
\hline Total methionine + cystine $(\%)$ & 0.718 & 0.718 & 0.718 & 0.718 & 0.718 \\
\hline Total methionine (\%) & 0.423 & 0.423 & 0.423 & 0.423 & 0.423 \\
\hline Crude protein $(\%)$ & 18.00 & 18.00 & 18.00 & 18.00 & 18.00 \\
\hline Sodium (\%) & 0.182 & 0.182 & 0.182 & 0.182 & 0.182 \\
\hline Total threonine $(\%)$ & 0.709 & 0.709 & 0.709 & 0.709 & 0.709 \\
\hline Total tryptophan $(\%)$ & 0.215 & 0.215 & 0.215 & 0.215 & 0.215 \\
\hline
\end{tabular}

(1)Mineral and vitamin supplement (composition per $\mathrm{kg}$ ): vitamin A, 2,500,000 IU; vitamin D3, 834,000 IU; vitamin E, 2,000 IU; vitamin K3, 500 mg; vitamin B1, $334 \mathrm{mg}$; vitamin B2, 1,500 mg; vitamin B6, $334 \mathrm{mg}$; vitamin B12, 3,333 mg; niacin, 5,000 mg; calcium pantothenate, 2,000 mg; folic acid, $100 \mathrm{mg}$; biotin, $6.67 \mathrm{mg}$; choline chloride, $50 \mathrm{~g}$; methionine, $234 \mathrm{~g}$; ferrous (Fe) sulfate, 6,660 mg; copper (Cu) sulfate, 2,220 mg; manganese (Mn) sulfate, $20 \mathrm{~g}$; zinc (Zi) sulfate, $17.34 \mathrm{~g}$; calcium iodate (I), $400 \mathrm{mg}$; sodium selenite (Se), $100 \mathrm{mg}$; ethoxyquin, $25 \mathrm{~g}$; halquinol, $12 \mathrm{~g}$; excipient q.s.p, $1.000 \mathrm{~g}$. ${ }^{(2)} \mathrm{Neutral}$ detergent fiber. ${ }^{(3)}$ Acid detergent fiber. 
using a micrometer. Albumen-height and egg weight were utilized in the calculation of Haugh units (HU) by the equation $\mathrm{HU}=100 \log \left(\mathrm{H}+7.57-1.7 \mathrm{~W}^{0.37}\right)$, in which: $\mathrm{H}$ is the albumen height $(\mathrm{mm})$; and $\mathrm{W}$ is the egg weight $(\mathrm{g})$.

Shell thickness was measured with a digital caliper rule, with $0.01 \mathrm{~mm}$ precision, in three points of egg equatorial region. To determine egg traits, yolks were separated and weighed on the precision scale AD1000. Eggshells were washed, left to dry for 48 hours, and then weighed. Percentages of yolk and shell were obtained as the ratio between the weight of each portion and egg weight; and the percentage of albumen was determined by difference as following: $\%$ albumen $=100-(\%$ yolk $+\%$ shell $)$.

At the end of the experiment, the birds were weighed, and one bird whose weight was similar to the average weight of each plot was selected per plot. Once identified, birds were moved to the slaughterhouse and sacrificed by cervical dislocation. After the slaughter, drumsticks and thighs were removed, identified, weighed on the digital scale $\mathrm{AD} 1000$, and frozen in a freezer at $-20^{\circ} \mathrm{C}$, where they remained until the moment of deboning.

For deboning, pieces were removed from the freezer and left to thaw in a domestic refrigerator (temperature of $4^{\circ} \mathrm{C}$, for 12 hours), then they were placed on countertops until reaching room temperature. Subsequently, thigh and drumstick were weighed, identified, and immersed in boiling water for ten minutes. Next, they were deboned using a scalpel.

Only the right tibiae were used to evaluate bone quality. The bones were measured using a digital caliper rule, and weighed on the electronic scale AD1000. Bone density was evaluated using the Seedor index, obtained by the ratio between weight (mg) and length (mm) (Seedor et al., 1991).

Strength and deformity parameters of bone in its natural state (right tibia) were performed using a Testop/ Ronald triaxial mechanical press (Indústria e Comércio Ronald Top Ltda., Rio de Janeiro, RJ, Brazil) with $150 \mathrm{~kg}$ capacity. The bones were placed horizontally, supported on their edges on a wood support, and then a compression force was applied to the center of each bone. The maximum force applied to the bone, before its break was considered the breaking strength $\left(\mathrm{kgf} \mathrm{cm}^{-2}\right)$. Bone deformity $(\mathrm{mm})$ was measured by recording, on an analogical extensometer, the flexion of each bone in relation to its horizontal position until its break by the action of the applied force.

The chemical composition of bones was determined at the Animal Nutrition Laboratory, of the Animal Science Department, at Universidade Federal do Ceará, using the right bones of the tibia which were removed from the freezer and placed on a countertop for thawing. Subsequently, they were transferred to proper containers, weighed, and dried in a forced-ventilation oven at $55^{\circ} \mathrm{C}$ for 72 hours. Next, the samples were taken out and defatted in a Soxhlet extractor for eight hours, then put back in the forced-ventilation oven at $55^{\circ} \mathrm{C}$, for 72 hours, and weighed again to determine the dry matter. After weighing, bones were ground in a ball mill, and ground samples were conditioned in labeled plastic bags for subsequent determination of the dry matter (DM) and mineral matter (MM), using the methodology described by Silva \& Queiroz (2002).

Data statistical analyses were performed by the SAS 9.2 (2004) software. These data were initially subjected to the Shapiro-Wilk test, to check the normality of residuals, and Levene test for homogeneity between the variances. Analysis of variance was subsequently performed using the SAS 9.2 (2004) software, in a factorial model in which the limestone particle size, supplied light, and respective interactions between these factors were included. To evaluate the effect of the change in limestone particle sizes, with substitution of fine for coarse limestone in the diet, a regression analysis was conducted, considering the different levels of limestone being replaced $(0,25,50,75$, and $100 \%)$. For the other factors of the model, means were compared by the SNK test, at 5\% probability.

\section{Results and Discussion}

There was no significant interaction between limestone particle sizes and lighting regimes for all evaluated parameters, just as there was no statistical effect of the factors separately (Table 2).

The results obtained for the effect of limestone particle sizes on the performance of the birds can be associated with the absence of significant influence of this factor on feed intake. If the change of the particle size of the calcium source does not affect the feed intake significantly, as a consequence, performance will not be affected, considering that birds subjected to different limestone particle sizes show enough nutrient 
intake to have good performance (Saunders-Blades et al., 2009; Araújo et al., 2011).

The lack of significant influence of the prolonged light period with the use of artificial light on the layers performance may be associated with the length of daytime in the region $\left(3^{\circ} 43^{\prime} 02^{\prime \prime} \mathrm{S}, 38^{\circ} 32^{\prime} 35^{\prime \prime} \mathrm{W}\right)$, which was 12 hours and $13 \mathrm{~min}$ of natural light per day, during the experimental period and, therefore, even being subjected to natural light only, birds received 1 hour and 13 min of light during their photosensitivity period, which was certainly enough to ensure hormone production to achieve good performance. The layers are indeed photostimulated with more than 12 hours of light (Jácome et al., 2014).

As to the use of artificial light for layers, similar effects to those obtained herein were reported by Gewehr \& Freitas (2007), and Oliveira et al. (2013). They observed that the use of natural lighting (+/- 12 hours) provided similar performance to the program using artificial light to supply 16 hours of light to the layers. Thus, the researchers concluded that natural illumination makes it possible to maintain the productive performance of commercial white-egg layers in tropical regions. Also, it should be considered that there was no significant influence of the lighting program on feed intake, which enabled sufficient nutrients for the good performance of laying hens.
As to the results regarding egg quality (Table 3), neither significant interaction was found among the studied factors, nor significant effect of particle sizes with inclusion of coarse limestone replacing the fine limestone on the evaluated parameters. For lighting, it was observed that there was a significant difference only for the Haugh units, wherein the eggs from birds subjected to artificial light showed higher Haugh unit values than those receiving natural light only, irrespective of the level of coarse limestone substituting its fine version in the diets.

The diets were formulated to be isonutrients. Thus, the absence of significant influence of limestone on the internal or eggshell quality may be associated with the fact that the birds subjected to different treatments had ingested nutrients in sufficient quantities to produce a good internal and eggshell quality. Similar results were reported by Jardim Filho et al. (2005a), Saunders-Blade et al. (2009), Araújo et al. (2011), and Oliveira et al. (2013).

Some researchers (Lichovnikova, 2007; Skřivan et al., 2010) have reported improvement of the eggshell quality with the use of limestone in large particles; however, this was not observed in the present study. Usually, coarser particles are efficient to improve shell quality, even when laying hens fed inadequate calcium levels or are exposed to factors that reduce

Table 2. Performance of commercial laying hens subjected to different limestone particle sizes and two lighting regimes.

\begin{tabular}{|c|c|c|c|c|c|}
\hline Treatment & $\begin{array}{c}\text { Intake } \\
\text { (g per bird per day) } \\
\end{array}$ & $\begin{array}{c}\text { Egg-laying } \\
\text { (\% per bird per day) }\end{array}$ & $\begin{array}{c}\text { Egg weight } \\
(\mathrm{g})\end{array}$ & $\begin{array}{c}\text { Egg mass } \\
\text { (g per bird per day) }\end{array}$ & $\begin{array}{c}\text { Feed conversion } \\
\left(\mathrm{kg} \mathrm{kg}^{-1}\right)\end{array}$ \\
\hline \multicolumn{6}{|l|}{ Coarse limestone (\%) } \\
\hline 0 & 94.29 & 92.14 & 56.55 & 52.13 & 1.82 \\
\hline 25 & 94.16 & 92.39 & 57.30 & 52.97 & 1.78 \\
\hline 50 & 94.82 & 94.59 & 57.63 & 54.51 & 1.74 \\
\hline 75 & 94.43 & 94.33 & 57.28 & 54.03 & 1.75 \\
\hline 100 & 93.17 & 94.66 & 56.80 & 53.76 & 1.73 \\
\hline Mean & 94.17 & 93.62 & 57.12 & 53.48 & 1.76 \\
\hline \multicolumn{6}{|l|}{ Artificial light } \\
\hline Yes & 94.12 & 94.04 & 57.41 & 53.99 & 1.74 \\
\hline No & 94.23 & 93.21 & 56.81 & 52.97 & 1.78 \\
\hline Mean & 94.18 & 93.63 & 57.11 & 53.48 & 1.76 \\
\hline Effect Anova & & & $\mathrm{p}$-value & & \\
\hline Coarse limestone & 0.8290 & 0.4369 & 0.4806 & 0.3335 & 0.1317 \\
\hline Artificial light & 0.8988 & 0.4666 & 0.1490 & 0.1969 & 0.0767 \\
\hline Limestone $\times$ light & 0.8530 & 0.4824 & 0.3514 & 0.2316 & 0.1595 \\
\hline Regression analysis & & & p-value & & \\
\hline Linear & 0.5929 & 0.3326 & 0.0697 & 0.0984 & 0.1427 \\
\hline Quadratic & 0.3669 & 0.6241 & 0.0729 & 0.2018 & 0.4001 \\
\hline$\overline{C V}(\%)$ & 3.45 & 4.28 & 2.53 & 5.11 & 4.50 \\
\hline
\end{tabular}


its utilization (Pizzolante et al., 2009). Other studies showed that large particle sizes have no effect on shell quality, even when calcium levels in the diet are adequate (Pelicia et al., 2009; Pizzolante et al., 2009; Saunders-Blade et al., 2009).

Frequently, the results of research show that artificial lighting programs influence egg production, but not egg quality parameters (Jácome et al., 2014). However, in the present work, there was an improvement in the quality of the albumen, with increasing length of the lighting period. This effect can be attributed to the impacts of light on the functioning of the bird oviduct because the albumen is formed under the control of estrogen, androgen, and progesterone hormones, whose production is regulated by the luminous stimuli received by the birds, such that secretion of these hormones may be reduced in a shorter luminous period (Silversides et al., 2006).

In the assessment of bone quality of laying hens (Table 4), no significant effect was observed on bone density, for the use of artificial light or interaction between limestone particle sizes and lighting regimes; bone was measured for density by the Seedor index, and for deformity, breaking strength, and mineral matter content of the tibia. The deformity, breaking strength, and mineral matter content of the tibia were influenced by the change of the limestone particle sizes in diets for the layers. The increasing levels of coarse limestone resulted in a linear effect on the deformity $\left(\mathrm{y}=3.296+0.0084 \mathrm{x}, \mathrm{R}^{2}=0.88\right)$, breaking strength $\left(\mathrm{y}=5.17+0.0111 \mathrm{x}, \mathrm{R}^{2}=0.97\right)$, and mineral matter $(\mathrm{y}$ $\left.=50.346+0.0549 \mathrm{x}, \mathrm{R}^{2}=0.89\right)$ of the tibia. Deformity, bone strength, and mineral matter improved as the proportion of coarse limestone in the diet was increased.

Based on the results obtained for bone deformity and breaking strength of the tibia, it can be inferred that addition of a calcium source with larger size particles may contribute to maintain bone integrity in laying hens at 39 week of age. These results can be associated; they are explained by the fact that coarser limestone particle sizes promote a greater accumulation of minerals in the bones; thus, as calcium solubilizes more slowly, it enables the presence of its particles in the gizzard, in the night period, promoting the availability of dietary calcium in the blood stream which, in turn, contributes the reduction bone calcium removal. Similar results to those obtained in the present study were reported by Saunders-Blades et al. (2009), Witt et al. (2009), Araújo et al. (2011), Cufadar et al. (2011), and Tunç \& Cufadar (2015). However, Jardim Filho et al. (2005b) evaluated different limestone particle sizes, and they did not observe a significant effect on mineral deposition or bone strength measured in tibia of laying hens.

Table 3. Egg quality of commercial laying hens subjected to different limestone particle sizes and two lighting regimes.

\begin{tabular}{|c|c|c|c|c|c|c|}
\hline Item & $\begin{array}{l}\text { Yolk } \\
(\%)\end{array}$ & $\begin{array}{c}\text { Albumen } \\
(\%)\end{array}$ & $\begin{array}{l}\text { Shell } \\
(\%)\end{array}$ & $\begin{array}{l}\text { Haugh } \\
\text { unit }\end{array}$ & $\begin{array}{l}\text { Specific } \\
\text { gravity }\end{array}$ & $\begin{array}{c}\text { Shell thickness } \\
(\mathrm{mm})\end{array}$ \\
\hline \multicolumn{7}{|l|}{ Coarse limestone (\%) } \\
\hline 0 & 23.64 & 66.77 & 9.63 & 86.25 & 1.087 & 0.26 \\
\hline 25 & 23.53 & 66.69 & 9.81 & 86.41 & 1.091 & 0.26 \\
\hline 50 & 23.27 & 66.80 & 9.98 & 86.54 & 1.093 & 0.26 \\
\hline 75 & 23.53 & 66.67 & 11.33 & 86.37 & 1.094 & 0.26 \\
\hline 100 & 23.80 & 66.33 & 9.91 & 87.21 & 1.094 & 0.26 \\
\hline Mean & 23.55 & 66.65 & 10.13 & 86.35 & 1.092 & 0.26 \\
\hline \multicolumn{7}{|l|}{ Artificial light } \\
\hline Yes & 23.44 & 66.76 & 10.43 & $87.17 \mathrm{a}$ & 1.092 & 0.26 \\
\hline No & 23.67 & 66.54 & 9.83 & $85.54 \mathrm{~b}$ & 1.091 & 0.26 \\
\hline Mean & 23.56 & 66.65 & 10.13 & 86.36 & 1.092 & 0.26 \\
\hline Effects Anova & \multicolumn{6}{|c|}{ p-value } \\
\hline Coarse limestone & 0.5606 & 0.7691 & 0.4091 & 0.3287 & 0.0800 & 0.1860 \\
\hline Artificial light & 0.2552 & 0.3709 & 0.3276 & 0.0038 & 0.1730 & 0.1430 \\
\hline Limestone $\times$ light & 0.4646 & 0.4617 & 0.3917 & 0.9575 & 0.2970 & 0.6630 \\
\hline Regression analysis & \multicolumn{6}{|c|}{ p-value } \\
\hline Linear & 0.1756 & 0.6791 & 0.3095 & 0.6705 & 0.0852 & 0.2129 \\
\hline Quadratic & 0.1232 & 0.4590 & 0.4361 & 0.3825 & 0.1252 & 0.4649 \\
\hline$\overline{\mathrm{CV}(\%)}$ & 3.03 & 1.33 & 21.11 & 2.16 & 0.18 & 3.41 \\
\hline
\end{tabular}


As to lighting program and bone quality, no significant effect was observed. This can be explained by lack of significant difference between feed intake and egg production in the treatments subjected to the different lighting programs, as the bone quality of laying hens are dependent on the output level (Silversides et al., 2006) and on the availability of calcium for eggshell formation (Saunders-Blades et al., 2009).

The original hypothesis of the present work was that not providing artificial light for laying hens would decrease feed intake in the dark period. Consequently, it would reduce calcium intake during this period and the supply of this mineral for the eggshell formation, which would force a greater bone calcium mobilization to meet the higher demand during the eggshell formation, adversely affecting bone quality of the birds. This problem could be solved with the benefits of offering a source of calcium with larger particles. However, this effect was not confirmed because bone quality of laying hens was not influenced by lighting program, as well as no interaction was observed between limestone particle sizes and lighting regimes.

Table 4. Bone quality parameters of laying hens subjected to different levels of coarse limestone and two lighting regimes $^{(1)}$.

\begin{tabular}{|c|c|c|c|c|}
\hline Item & $\begin{array}{c}\text { Seedor index } \\
\left(\mathrm{mg} \mathrm{mm}^{-1}\right)\end{array}$ & $\begin{array}{l}\text { Deformity }{ }^{(2)} \\
(\mathrm{mm})\end{array}$ & $\begin{array}{l}\begin{array}{l}\text { Strength } \\
\left(\text { kgf cm }^{-2}\right)\end{array} \\
\end{array}$ & $\begin{array}{c}\text { Mineral } \\
\text { matter }^{(4)}(\%)\end{array}$ \\
\hline \multicolumn{5}{|l|}{ Coarse limestone (\%) } \\
\hline 0 & 61.14 & $3.23 b$ & $5.19 b$ & $51.09 \mathrm{c}$ \\
\hline 25 & 61.44 & $3.45 \mathrm{ab}$ & $5.37 \mathrm{~b}$ & $51.49 \mathrm{bc}$ \\
\hline 50 & 61.50 & $3.90 \mathrm{a}$ & $5.64 \mathrm{ab}$ & $52.09 \mathrm{bc}$ \\
\hline 75 & 61.85 & $4.00 \mathrm{a}$ & $6.12 \mathrm{a}$ & $54.17 \mathrm{~b}$ \\
\hline 100 & 62.17 & $4.01 \mathrm{a}$ & $6.20 \mathrm{a}$ & $56.61 \mathrm{a}$ \\
\hline Mean & 61.62 & 3.72 & 5.70 & 53.09 \\
\hline \multicolumn{5}{|l|}{ Artificial light } \\
\hline Yes & 61.79 & 3.73 & 5.65 & 53.28 \\
\hline No & 61.49 & 3.70 & 5.76 & 53.05 \\
\hline Mean & 61.64 & 3.72 & 5.71 & 53.17 \\
\hline Effect Anova & \multicolumn{4}{|c|}{ p-value } \\
\hline Coarse limestone & 0.2981 & 0.0054 & 0.0017 & 0.0001 \\
\hline Artificial light & 0.3562 & 0.8404 & 0.5114 & 0.7515 \\
\hline Limestone $\times$ light & 0.3548 & 0.7149 & 0.3867 & 0.7062 \\
\hline Regression analysis & \multicolumn{4}{|c|}{ p-value } \\
\hline Linear & 0.7077 & 0.0002 & 0.0001 & 0.0001 \\
\hline Quadratic & 0.7889 & 0.2083 & 0.9799 & 0.0605 \\
\hline CV (\%) & 1.08 & 14.07 & 10.60 & 4.48 \\
\hline
\end{tabular}

${ }^{(1)}$ Means followed by equal letters, do not differ by SNK test, at $5 \%$ of probability. ${ }^{(2)}$ Significant linear effect $\left(\mathrm{y}=3.296+0.0084 \mathrm{x}, \mathrm{R}^{2}=0.88\right) .{ }^{(3)}$ Significant linear effect $\left(\mathrm{y}=5.17+0.0111 \mathrm{x}, \mathrm{R}^{2}=0.97\right) .{ }^{(4)}$ Significant linear effect $\left(y=50.346+0.0549 x, R^{2}=0.89\right)$.

\section{Conclusions}

1. Larger particle sizes of limestone in the diet do not influence the performance or egg quality of commercial laying hens from 18 to 39 weeks of ages, but improve the bone quality of these birds.

2. The use of artificial light does not affect performance or bone quality of laying hens, but benefits the albumen quality measured in Haugh units.

\section{Acknowledgments}

To Fundação Cearense de Apoio ao Desenvolvimento Científico e Tecnológico (Funcap), for financial support and scholarship awarded.

\section{References}

ARAÚJO, J.A. de; SILVA, J.H.V. da; COSTA, F.G.P.; SOUSA, J.M.B. de; GIVISIEZ, P.E.N.; SAKOMURA, N.K. Effect of the levels of calcium and particle size of limestone on laying hens. Revista Brasileira de Zootecnia, v.40, p.997-1005, 2011. DOI: 10.1590/S1516-35982011000500009.

CUFADAR, Y.; OLGUN, O.; YILDIZ, A.Ö. The effect of dietary calcium concentration and particle size on performance, eggshell quality, bone mechanical properties and tibia mineral contents in moulted laying hens. British Poultry Science, v.52, p.761-768, 2011. DOI: $10.1080 / 00071668.2011 .641502$.

FARIA, D.E. de; JUNQUEIRA, O.M.; SAKOMURA, N.K.; SANTANA, A.E. Sistemas de alimentação e suplementação de farinha de casca de ostras sobre o desempenho e a qualidade da casca dos ovos de poedeiras comerciais. Revista Brasileira de Zootecnia, v.29, p.1394-1401, 2000. DOI: 10.1590/ S1516-35982000000500018.

FREITAS, E.R.; SAKOMURA, N.K.; GONZALEZ, M.M.; BARBOSA, N.A.A. Comparação de métodos de determinação da gravidade específica de ovos de poedeiras comerciais. Pesquisa Agropecuária Brasileira, v.39, p.509-512, 2004. DOI: 10.1590/ S0100-204X2004000500014.

FREITAS, H.J. de; COTTA, J.T. de B.; OLIVEIRA, A.I.G. de; GEWEHR, C.E. Avaliação de programas de iluminação sobre o desempenho zootécnico de poedeiras leves. Ciência e Agrotecnologia, v.29, p.424-428, 2005. DOI: 10.1590/ S1413-70542005000200021.

GEWEHR, C.E.; FREITAS, H.J. de. Iluminação intermitente para poedeiras criadas em galpões abertos. Revista de Ciências Agroveterinárias, v.6, p.54-62, 2007.

JÁCOME, I.M.T.D.; ROSSI, L.A.; BORILLE, R. Influence of artificial lighting on the performance and quality of commercial layers: a review. Revista Brasileira de Ciência Avícola, v.16, p.337-343, 2014. DOI: 10.1590/1516-635X1604337-344.

JARDIM FILHO, R. de M.; STRINGHINI, J.H.; CAFÉ, M.B.; LEANDRO, N.S.M.; CUNHA, W.C.P. da; NASCIMENTO 
JÚNIOR, O. Influência das fontes e granulometria do calcário calcítico sobre o desempenho e qualidade da casca dos ovos de poedeiras comerciais. Acta Scientiarum. Animal Science, v.27, p.35-41, 2005a. DOI: 10.4025/actascianimsci.v27i1.1239.

JARDIM FILHO, R. de M.; STRINGHINI, J.H.; CAFÉ, M.B.; ANDRADE, M.A.; SAKAMOTO, M.I.; FRANCO, J.R.G. Influência das fontes e granulometria do calcário calcítico sobre a densidade, resistência e composição mineral da tíbia de poedeiras comerciais. Acta Scientiarum. Animal Science, v.27, p.23-28, 2005b. DOI: $10.4025 /$ actascianimsci.v27i1.1238.

LICHOVNIKOVA, M. The effect of dietary calcium source, concentration and particle size on calcium retention, eggshell quality and overall calcium requirement in laying hens. British Poultry Science, v.48, p.71-75, 2007. DOI: 10.1080/00071660601148203.

OLIVEIRA, A.N. de; FREITAS, E.R.; FILGUEIRA, T.M.B.; CRUZ, C.E.B.; NASCIMENTO, G.A.J. do. Limestone particle size and artificial light for laying hens in the second laying cycle. Revista Brasileira de Zootecnia, v.42, p.481-488, 2013. DOI: $10.1590 /$ S1516-35982013000700004.

PELICIA, K.; GARCIA, E.; MÓRI, C.; FAITARONE, A.B.G.; SILVA, A.P.; MOLINO, A.B.; VERCESE, F.; BERTO, D.A. Calcium levels and limestone particle size in the diet of commercial layers at the end of the first production cycle. Brazilian Journal of Poultry Science, v.11, p.87-94, 2009. DOI: 10.1590/ S1516-635X2009000200003.

PIZZOLANTE, C.C.; SALDANHA, E.S.P.B.; LAGANÁ, C.; KAKIMOTO, S.K.; TOGASHI, C.K. Effects of calcium levels and limestone particle size on the egg quality of semi-heavy layers in their second production cycle. Brazilian Journal of Poultry Science, v.11, p.79-86, 2009. DOI: 10.1590/S1516-635X2009000200002.

ROSTAGNO, H.S.; ALBINO, L.F.T.; DONZELE, J.L.; GOMES, P.C.; OLIVEIRA, R.F. de; LOPES, D.C.; FERREIRA, A.S.;
BARRETO, S.L. de T. Tabelas brasileiras para aves e suínos: composição de alimentos e exigências nutricionais. 3.ed. Viçosa: Ed. da UFV, 2011. 252p.

SAUNDERS-BLADES, J.L.; MACISAAC, J.L.; KORVER, D.R.; ANDERSON, D.M. The effect of calcium source and particle size on the production performance and bone quality of laying hens. Poultry Science, v.88, p.338-353, 2009. DOI: 10.3382/ ps.2008-00278.

SEEDOR, J.G.; QUARRUCCIO, H.A.; THOMPSON, D.D. The bisphosphonate alendronate (MK-217) inhibits bone loss due to ovariectomy in rats. Journal of Bone and Mineral Research, v.6, p.339-346, 1991. DOI: 10.1002/jbmr.5650060405.

SILVA, D.J.; QUEIROZ, A.C. de. Análise de alimentos: métodos químicos e biológicos. 3.ed. Viçosa: Ed. da UFV, 2002. 167p.

SILVERSIDES, F.G.; KORVER, D.R.; BUDGELL, K.L. Effect of strain of layer and age at photostimulation on egg production, egg quality, and bone strength. Poultry Science, v.85, p.1136-1144, 2006. DOI: $10.1093 / \mathrm{ps} / 85.7 .1136$.

SKŘIVAN, M.; MAROUNEK, M.; BUBANCOVÁ, I.; PODSEDNÍČEK, M. Influence of limestone particle size on performance and egg quality in laying hens aged 24-36 weeks and 56-68 weeks. Animal Feed Science and Technology, v.158, p.110-114, 2010. DOI: 10.1016/j.anifeedsci.2010.03.018.

TUNÇ, A.R.; CUFADAR, Y. Effect of calcium sources and particle size on performance and eggshell quality in laying hens. Turkish Journal of Agriculture - Food Science and Technology, v.3, p.205-209, 2015.

WITT, F.H. de; KULEILE, N.P.; VAN DER MERWE, H.J.; FAIR, M.D. Effect of limestone particle size on egg production and eggshell quality of hens during late production. South African Journal of Animal Science, v.39, p.37-40, 2009.

Received on January 26, 2015 and accepted on June 5, 2015

Pesq. agropec. bras., Brasília, v.50, n.8, p.718-725, ago. 2015 DOI: $10.1590 / \mathrm{S} 0100-204 X 2015000800010$ 